The author explains how Russian ethnography was created in the second half of the 18th century and the first half of the 19th century. She divides this timespan into shorter periods. In each of these periods she presents crucial events that left an important mark on ethnographic works (e.g. research expeditions) as well as outstanding individuals who infuenced the development of ethnographic science in Russia.

Keywords: Russia, ethnography, historical overview, 18th century, 19th century, research expeditions
Avtorica v prispevku pojasni, kako se je ruska etnografija oblikovala $v$ drugi polovici 18. stoletja in prvi polovici 19. stoletja, pri čemer ta časovni razpon razdeli na več krajših obdobij. Predstavi bistvene dogodke, ki so zaznamovali etnografska dela (npr. raziskovalne odprave), in posameznike, ki so s svojimi deli vplivali na razvoj vede $v$ Rusiji.

Ključne besede: Rusija, etnografija, zgodovinski pregled, 18. stoletje, 19. stoletje, raziskovalne ekspedicije

\title{
TIME OF GREAT REFORMS
}

The first decades of the eighteenth century, an era of great reforms led by Peter I, were marked by changes in all areas of life in the Russian Empire. The foundation of the Russian Academy of Sciences in 1725 played an important role in these changes, as its entire activity was aimed mainly at a comprehensive study of its native country. At the beginning of the eighteenth century, the Russian Academy of Sciences organized expeditions that pursued only scientific purposes - the expedition of Daniel G. Messerschmidt to Siberia (1720-1727), the Great Northern Expedition of Gerhard F. Müller and Johann G. Gmelin (1733-1743), and the expedition of Stepan P. Krasheninnikov, the purpose of which was to establish a sea route to America and to study the northern coast of Siberia (1737-1741). The last expedition results were documented in the Description of the Kamchatka Land by Krasheninnikov, a work that interested not only Russian scientists and travellers but also the Western ones.

Along with the advance of the Russian explorers to the Northeast and their search for routes to America, the Southeast regions of the country or South Transurals also underwent an extension. The 1730s marks the beginning of the studies of Central Asia and the intense Russian colonization of these lands. In 1737, Vasily N. Tatishchev (1686-1750) headed the Orenburg expedition of the Academy of Sciences, the purpose of which was to collect historic and ethnographic materials. His initiative was taken up by Peter I. Rychkov (1712-1777), who also studied the territory of the Orenburg Region and the South Transurals region and wrote up his findings in the book Orenburg Topography (1762), which was later translated into German. 
The year 1741 marks the initiation of a series of expeditions to the newfound lands after the discovery of the Aleutian Islands and the Northwest coast of America by Aleksey I. Chirikov and Vitus Bering. The merchants rushed there, attracted primarily by fur resources in coastal areas (beaver, polar fox and other furs). From 1759 to 1762 , Stepan Glotov and Savva Ponomarev visited different regions, including the islands of Umnak and Unalaska at the Eastern part of the Aleutian archipelago. During these voyages, sailors and merchants came in contact with the native population - the Aleuts, the Kodiaks - and brought back information about these peoples. The most valuable of these reports concerned the population of the Aleutian Islands provided by Stepan Cherepanov, Ivan Korovin, Ivan Soloviev and Vasily Shilov (in the 1760s), which were published only recently by Alexander I. Andreev (1948). Their reports and notes turned up at the Senate and Admiralty Boards in Saint Petersburg. It was with great difficulty that the government agreed to organize new expeditions: in 1764, a special expedition under the guidance of captain Pyotr Krenitsyn and captain-lieutenant Mikhail Levashev was organized to explore the Aleutian Islands. It was unsuccessful because its members failed to establish friendly relations with the population of Alaska. The expedition returned to Saint Petersburg with heavy losses in 1771 . Krenitsyn died on his way back. The sea logs of Levashev that contained ethnographic material about the Aleuts of Unalaska Island were thankfully preserved.

The Academy of Sciences continued organizing a series of expeditions from 1768 to 1774. The expeditions of the German academician Peter S. Pallas (1741-1811) are worthy of mention in this context. Pallas worked in Russia on the right and left banks of the Volga, the Orenburg steppes, Southern Urals, Western Siberia, Eastern Siberia and the Transbaikal regions (1768-1774). The results of these expeditions were published in his major works: Journey through Various Provinces of the Russian Empire (Saint Petersburg, 1788) and Collection of Historical Data about Mongol People (Saint Petersburg, 1776-1801). The latter, two-volume research has been of extrinsic value for the study of historical ethnography to date, as it is based on genuine Mongol manuscripts. In this context it is also worth mentioning the expeditions of his disciples: the expeditions of Vasily F. Zuev (1754-1794) to Mangazeya, across South Russia (Crimea, Bessarabia) and to Turkey; and the expeditions led by Ivan I. Lepyokhin (1740-1802) to the Volga Region and Orenburg steppes, the South Transurals region and Middle Transurals region.

In his work entitled Description of Peoples of Other Religions - the Ostyaks and the Samoyeds, Living in Siberian Guberniya in Berezovsky Uyezd", Zuyev accurately described for the first time the way of life of the Khanty and the Mansi, comparing them with each other. In addition, he depicts the reported exogamy among the Ostyaks as well as other features of life of Ural families. Daily Notes of Travel across the Provinces

"Guberniya" = governorate; "uyezd" = county. 
of the Russian State (Saint Petersburg, 1795, 4 parts) by Lepyokhin contains valuable ethnographic essays about the material and intellectual culture of the Mordovians, the Chuvash, the Tatars, unbaptized Kalmyks and their Lamaist clergy (Part 1), the Bashkirs, the Voguls, the Komi-Permyaks and the Zyrians, the Russians Pomors and others. After the death of Lepyokhin, the fourth volume of his Daily Notes was finished and prepared for publication by his companion and disciple Nikolai Y. Ozeretskovsky (1750-1827). Under the instruction of Lepyokhin, Ozeretskovsky himself led additional expeditions - from Arkhangelsk to Kola then to Mezen and further to the East, as he describes in the $4^{\text {th }}$ volume of Daily Notes. Ozeretskovsky, already being an academician, later traveled around the lake Ilmen, the Ladoga and Onega lakes and other regions of Russia. In his Review of Areas from Saint Petersburg to Staraya Russa and the Way Back (Saint Petersburg, 1808), he provides a series of ethnographic sketches. In addition, as a Russian patriot he paid attention to the fact that the Russian people were oppressed and thus suffered seriously, but he nevertheless believed that it was essential to reckon with the power of enlightenment. The origins of the revolutionarydemocratic stream in Russian ethnography that originated later can be traced back to these progressive figures of Russian science of the eighteenth century.

\section{ETHNIC OVERVIEW OF THE RUSSIAN EMPIRE}

As a result of long-term scientific expeditions, travels and the systematic collection of material on preconceived programs, Russian science possessed a vast stock of ethnographic information on the majority of peoples of Russia in the last decades of the eighteenth century. Based on this information, it was possible to create the first consolidated ethnographic work - a review of the peoples in the Russian Empire, a description of their economy and the way of life. From 1776 to 1780 , the complete Description of All Peoples Living in the Russian State (Georgi 1776-1777) was thus ready to meet the growing interest of the educated Russian society in the peoples of its country. The author of this book was Johann G. Georgi (1729-1802), a member of the great Physical Expedition who had returned to Saint Petersburg not long before. The book was published in German in Saint Petersburg and consisted of four parts, the first three of which were published both in Russian and in French. In Georgi's opinion, the reason for the creation of such work was the necessity to uphold the imperial ambitions of Russia. He wrote that hardly any other country in the world had such a wide variety of different nations, remnants of nationalities, and colonies as the Russian state. There wasn't enough exact knowledge of these peoples, therefore it was necessary to collect information and organize what was accumulated. Georgi drew sources for this major work from his own observations and notes on his trips to observe the Laplanders, the Finns, the Cheremis, the Chuvash, the Voguls, the Ostyaks, the Permyaks, the 
Bashkirs, the Meshchera, the Tungus, the Buryats, the Kalmyks, etc. In addition, he used the works of Gmelin Jr., Krasheninnikov, Pallas, Lepyokhin, Rychkov Jr. as well as the chosen works of foreign scientists. Thus the first consolidated ethnographic work on the peoples of Russia was based on serious scientific research. The attempt to give an overall picture of the ethnic composition of the Russian Empire and its particular peoples' way of life was made in Russian and European science for the first time.

Therefore, interest in the way of life of the non-Russian ("inorodchesky") population existing on the vast expanses of Russia was defined first of all by practical motives, administrative and fiscal needs, as it was in times before Peter I. From the beginning of the eighteenth century onwards, practical interest began to be accompanied with academic ones, but they were guided by similar motives such as the knowledge of all the regions of the vast state with their multilingual population for the purpose of consolidation, discovery and development of their resources. It is no coincidence that all expeditions were sent to the outskirts of the Russian Empire. However, in the second half of the $18^{\text {th }}$ century, the objective need arose to recognize its own people - the Russian peasantry.

The rising interest in the Russian people is associated with the name of Mikhail V. Lomonosov (1711-1765), who played a great role in the formation and development of Russian ethnography. Lomonosov had been accumulating ethnographic knowledge since childhood. A son of a Pomor fisherman, he participated in fishing expeditions over almost the whole White Sea and the Barents Sea, during which time he met the Laplanders and the Samoyeds (the Nenets). Later he planned to make a detailed description of these peoples but never had the time to complete this project. By means of his Russian Grammar (1757), Lomonosov laid the basis not only for studying the Russian language and its grammatical structure but also for Russian dialectology. He was the first to point out the three dialects in the Russian language: Moscow, North and Ukrainian dialects. Lomonosov also compiled notes about the national way of life, published under the following titles: On the Reproduction and Protection of the Russian people; On the Extirpation of Idleness; On the Correction of Morals and Greater Enlightenment of People; On the Improvement of Agriculture; On the Improvement and Increase of Handicrafts and Arts. However, only one exemplar of these notes has been preserved, namely On the Reproduction and Protection of the Russian People, in which Lomonosov raised the question of several bad customs and other harmful phenomena hampering the Russian population growth and increasing the death rate. He wrote about the custom of early marriages, marriages between people of unequal age, the harm of forced marriages, of taking early monastic vows, the (lack of) control of infant mortality through education and obstetric knowledge, the harmful ecclesiastical custom of baptizing children in cold water, unrestrained gluttony, drinking, struggle with quackery and superstitions, etc. Lomonosov saw another reason for the tight situation of Russian peasantry, namely the yoke of feudal and serfdom oppression. However, he failed to understand the intrinsic meaning of this social reason for public disasters, only stating briefly that escapes abroad would occur because of "landowners oppressing peasants and 
soldiers' recruiting" (Lomonosov 1950-1983: 384-403). Thus Lomonosov's interest in the Russian national way of life was inseparable from a resolute struggle to improve it.

In addition, Lomonosov also had an academic interest in the Russian people: he raised the question of its origin and ancient history. This is evident in his work Ancient Russian History, which was published posthumously in 1766. In this work -- according to Tatishchev -- Lomonosov was seeking to shed light on the ancient origins of Russian history and expressed a number of interesting thoughts concerning the ethnogenesis of Russians. He showed that the history of the people was more ancient than the history of the state; moreover, the history of the people was more ancient than the ethnonym of the people itself. Lomonosov flatly rejected the "Norman theory" of the origin of the Russians and the Russian state; he considered Asia to be the native land of the Slavs and associated them with the Sarmatians. This theory was not his originally, as "Asian" and "Sarmatian" theories of the Slavic origin had been prevailing in European literature since the sixteenth century. However, Lomonosov also advanced the idea that contemporary people could not have been traced back to a single ancient ancestor. The struggle of Lomonosov with the "Norman" theory was not episodic; it was part of his general long-term struggle for the rights of the Russian science, Russian culture and the Russian language against foreign dominance, which at that time was greatly prevailing at the Academy of Sciences.

A great advocate of European enlightenment, Lomonosov also wanted the enlightenment to be beneficial to the Russian people and not to serve as a source of gain for foreign "half-baked experts" at a cost to the Russian people. Lomonosov was not alone in this opposition to German dominance and was supported by other Russian scientists: Tatishchev, Krasheninnikov, Lepyokhin, Zuev, Ozeretskovsky. It would be a mistake to see only the national moment in this patriotic struggle of Russian scientists against foreign dominance, e.g. the Russians against the Germans - as it was sometimes depicted by German historians (Tokarev 1966: 116). This struggle was of a social nature: the above mentioned progressive Russian scientists came from a lower class and were therefore advocates of peoples' rights and their enlightenment.

\section{EXPEDITIONS IN EARLY $19^{\mathrm{TH}}$ CENTURY}

The great Russian round-the-world expeditions of the first half of the nineteenth century (1805-1849) should be mentioned separately. They were motivated by economic and political reasons: the need to establish a direct connection with the domains in Northwest America (Alaska, the Aleutian Islands) recently acquired by Russia and to organize the supply of colonies based there. Russian seamen had already sailed through the Sea of Okhotsk and the Bering Sea to America in the eighteenth century; considerable ethnographic materials were collected at that time. From the beginning of the 
nineteenth century, expeditions to those regions brought more tangible results. They succeeded not only in the establishment of ties with Russian domains in America but also in completing major geographic research, the discovery of new lands and islands, and description of remote countries. Forty expeditions took place in the first half of the nineteenth century.

The first round-the-world cruise of the ships Nadezhda and Neva took place between 1803 and 1806 under the command of Adam Johann von Krusenstern and Yuri F. Lisyansky. The main purpose of the expedition was to establish sea links with Russian domains in America, to bring the Russian embassy to Japan as well as to research various other scientific problems. The ships made a journey -- partly together, partly on their own -- from Kronstadt across the Atlantic Ocean and the Pacific Ocean. Together they visited the coasts of South America, the Washington (Marquesas) Islands and the Hawaiian Islands. The descriptions of these two archipelagos inhabited by the Polynesian people were made for the first time. For example, Lisyansky collected materials concerning the social structure, public customs and religious beliefs of the Hawaiians. He also reported on the culture of Easter Island inhabitants, as well as of the inhabitants of the islands off Northwest coast of America (Russian settlement of Sitka Island and Kodiak Island). On his way back, he visited the Mariana Islands, the ports of South China - Macao -- where he met up again with the ship of Krusenstern -- and then he visited the Cape of Good Hope and the Azores.

Krusenstern on board of the Nadezhda sailed from the Hawaiian Islands straight to the lands of Kamchatka, and then on to Sakhalin and Japan. From there he brought almost unknown information about the Ainu and the Japanese, the peoples of Sakhalin, and particularly about the Gilyaks and the Kamchadals. The navigators brought back a valuable collections of items showing the way of life of the people they visited. The materials from expeditions of Krusenstern and Lisyansky were published in Russian as well as other languages.

Also worth mentioning are round-the-world expeditions led Vasily M. Golovnin from 1817 to 1819, who visited the lands of Brazil, the Cape of Good Hope, Tanna Island and Melanesia, Kamchatka and the coast of the Northwest America, as well as the expeditions led by Otto E. von Kotzebue from 1815 to 1818 and from 1823 to 1826. Kotzebue sailed along the Islands of the Pacific Ocean, where he made a number of important geographic discoveries including the discovery of several islands of the Tuamotu Archipelago and the island chain of the east part of the Marshall Archipelago belonging to Micronesia. Kotzebue was the first to provide a scientific description of East-Micronesians' way of life. He also visited Tahiti, Samoa, Hawaii and the Mariana Islands. Also famous were the expeditions of Faddei F. Bellingshausen and Mikhail P. Lazarev (1819-1821) that were organized only for scientific purposes - to study and research the region of the South Pole, which resulted in the discovery of the Antarctic continent - and the expedition of Fyodor P. Litke (1826-1829) the purpose of which 
was the exploration of the islands of the Barents Sea and the White Sea (describing the way of life of the Chukchi, the Eskimos, the Aleuts, the Tlingit). Litke also travelled to the islands of the tropical part of the Pacific Ocean, the Caroline Archipelago.

\section{WESTERN INFLUENCES ON RUSSIAN ETHNOGRAPHY}

Works of Western scientists played an important role in the development of Russian ethnography in the period presented in this paper, particularly the works of the outstanding German philosopher Johann G. Herder (1744-1803). The range of Herder's topics is extremely large: it contains literature, art, aesthetics theory, linguistics and history as a whole. The contribution of Herder's work to ethnography is of special interest in this regard, particularly his work Ideas for the Philosophy of History of Humanity (Herder 1829). In it he depicted an extraordinarily comprehensive picture of the historical development of humanity from antiquity to recent times, including all peoples in the world - including the most undeveloped ones. The leading idea of his whole work (and his entire ideology) is the unity of humanity, the unity of world history, and the denial of differences of any kind between undeveloped peoples and progressive ones. "The New-Zealand cannibal and a Fenelon, a Newton and the wretched pesheray, are all creatures of one and the same species". (Herder 1803, IV: 164) Certainly he did not ignore significant differences among the peoples in terms of their cultural patterns (as well as in terms of anthropological type and language). Similarly to Montesquieu, Herder was inclined to explain these differences in terms of geographical environment that in turn result in peculiarities in economic activity. In order to prove the dependence of culture on the geographical conditions, Herder provided a great deal of purely ethnographic examples. One of the most convincing examples was the indigenous population of America. As Herder correctly noticed, America had been populated in a certain natural way, from the northwest outward, so that the remote ancestors of the American Indians belong to the same group of people and their descendants should possess many common features. Having settled all over North and South America, the newcomers found themselves in different environmental conditions, to which they adapted. In addition, they developed different types of national character (Herder 1827, II: 42-46) that had an impact on the particularities of beliefs, mythology and poetry. Herder wrote:

Compare Greenlandic mythology with Indian one, Lapland mythology with Japanese one, Peruvian mythology with Negro one: the full geography of the poetic soul! The type of ideas of each nation is stamped as deep as it was inherited, this type has accustomed to its sky and earth, has grown out of its manner of life, has been inherited from fathers and forefathers. (Herder 1827, II: 122)

However, unlike Montesquieu, who considered this dependence on the natural environment to be static and did not argue for historical development, the conception of 
Herder was quite historical. He believed that we find the sequence of ascending forms of development even in nature; moreover, the development of humanity is drawn to us as an enormous progressive movement. A considerable part of Ideas for the Philosophy of History of Humanity is dedicated to the analysis of peoples, representing a kind of accessional stages of human race development. In this global process each nation takes its rightful place. Herder had a strong belief in the universal value of all that had been created by the work of each single nation. He strongly protested against the notions of Christian religion imposed by European colonialists on the peoples in colonial countries: he clearly saw this as a cover for plunder and violence. In Letters for the Advancement of Humanity (1790s), he puts forth this argument more strongly than in Ideas. Equally, Herder did not flatter himself with an imaginary cultural mission of Christianity:

Even Christianity, which began in the way of the government machine to influence other people has turned into a terrible oppression for them; Christianity defaced the unique nature of some peoples so much that one and a half thousand years was not enough to restore it. Would not it be better if the national spirit of peoples of the North - the Germanic peoples, the Gaels, the Slavs, etc. developed independently, without any barriers and in its pure form. (Herder 1959: 292)

Perhaps the most important idea that distinguished Herder from the French enlighteners was in the very concept of "national spirit" (Tokarev 1978: 130). French philosophers thought and wrote about humanity in general without paying attention to ethnic or national differences; ethnographic information concerning particular peoples principally served them as illustrations and obvious examples. They were mainly looking for something common to all the peoples rather than for something unique regarding each nation. Even Montesquieu, who stressed the distinctions among peoples, was interested in them only as evidence of geographical environmental influence on the individual. However, Herder believed that humanity was a single entity and its history was a single process; within the framework of such unity he looked intently at the peculiarity of each nation. For each of them he declared equal rights to develop and saw the "national spirit" bringing certain unique spiritual values. Relying on his constant idea of the original value of folk poetry works of all countries, Herder struggled relentlessly against enlighteners-rationalists with their cosmopolitan aspirations, advocates of Classicism (Winckelmann etc.), and imitators of foreign models. He encouraged the collection and study of the folklore of each nation. He wrote that even in Europe a number of nations remained unexplored and undescribed in this regard.

The Estonians and the Latvians, the Wends and the Slavs, the Poles and the Russians, the Frisians and the Prussians - their songs of this kind are collected unlike the songs of the Icelanders, the Danes, the Swedes, and of course unlike the English, the Ers, the Britons or the South peoples. And meanwhile there are so many individuals among them who are destined in the call of their duty to study language, morals, mentality, legends of yore and customs of their people! (Herder 1959: 69). 
The list of peoples according to Herder is quite confusing, but the idea is clear. This idea is repeated and varied in the whole range of Herder's works (On the Resemblance of Medieval English and German Poetry; On the Folk Songs, Comparison of Poetry of Different Peoples of Ancient and Modern Times; etc. - see Heym 1888). It is important to note that these particular ideas advocated by Herder exerted great influence on the revival of the national spirit among some peoples of Europe, particularly the Slavic ones. In particular, the activity of the first generation of Czech patriots known as "buditeli” (i.e. the Wakers), Josef Dobrovsky, Václav Hanka, František Palacký and others were inspired by Herder's doctrine on the national spirit coming into sight in amateur and folk arts, in folk-customs and ceremonies.

The distinguished German scholar, at first ordinary professor and later honorary foreign member of Saint Petersburg Academy of Sciences, August Ludwig von Schlözer (1735-1809), made a tremendous contribution to the study of Russian history. Schlözer was educated at the University of Wittenberg and the University of Göttingen, where he was a student of the famous Michaelis, who opened up a new era in history with his views on the relationship between the historical science and other scientific disciplines. At that time, he had an idea to study the East, but he could not afford it. Schlözer went from Göttingen to Sweden, where he studied the language and published Modern History of Literature in Sweden. In 1761, Schlözer was invited by Gerhard F. Müller and came to Russia to work as a family tutor and Müller's assistant in historical works with the salary of 100 rubles per year. From 1761 to 1767 , he worked at the Imperial Academy of Sciences, where he became an adjunct (since 1762) and then honorary member of Academy of Sciences (1769) as well as of the Society of History and Antiquities of Russia (1804). His publications of key historical records - the Nikon Chronicle, the Russkaya Pravda according to the Academic List, the Sudebnik (i.e. law code) of tsar Ivan the Terrible prepared in Saint Petersburg in 1760s as well as the first critical publication of the Primary Chronicle (Nestor: Russian Chronicles in Old Slavic Language) that he effectuated in Göttingen in 1802-1809 -- played a big role in the development of Russian history and paleography. In his last work, Schlözer referred for the first time in science to a detailed and extended critical analysis of Russian chronicles that included the study of their various lists in order to restore the "true" and "undamaged" text, work on the interpretation of certain words and phrases in their historical context, and an estimation of the reliability of described events and information from other historical records. "Nestor" created by Schlözer was actually the first fundamental source of study research in Russian historical science that strongly influenced later generations of Russian historians (Nikolay M. Karamzin, Mikhail T. Kachenovsky, Mikhail P. Pogodin). Schlözer became one of the authors of the so-called "Norman theory" exploring the origin of Russian statehood, had scientific debates with Lomonosov, and also assisted in publishing Russian History written by Tatishchev. Having returned to Germany, he took up a position of professor at the University of Göttingen where he taught history and statistics. In 1769, he pub- 
lished a detailed list of chronicles Annales Russici slavonice et latine cum varietate lectionis ex codd. X. Lib. I usque ad annum 879. His other works on the history of Russia are also well known: Das neue veränderte Russland (1767-1771), Geschichte von Lithauen (1872), Allgemeine Nordische Geschichte (1772), etc.

In 1803, he was awarded the order of Saint Vladimir of IV degree for his works on Russian history and was dignified with a noble title. In the late years of his life, he admitted and proved the authenticity of The Tale of Igor's Campaign. Before Schlözer, history was the subject of pure scholarship, an armchair scholar business, which was far from real life. He was the first one to see history as the study of state, cultural and religious life, the first one to bring it together with statistics, politics, geography and ethnography. Schlözer's works were one of the most important intermediaries in the process of cultural exchange taking place between Europe and Russia in the second half of the $18^{\text {th }}$ and the early $19^{\text {th }}$ centuries. Both while in Russia and after his return to Germany, Schlözer was active for a long time as a researcher and publisher of resources on the history of Russia, encouraging for it to be studied not only at the national level, but also at the European one. Secondly, he was actively spreading information concerning contemporary Russia in Europe as well as writing about Russian science and enlightenment. As a publicist, he contributed to the creation of a favorable image of Russia among European readers (particularly the German ones) in opposition to the prevailing opinion of the Russians generally characterized by "barbarity" and ignorance. Schlözer initiated important scientific contacts between German universities and Russia, and thanks largely to him, close relations were created between our country and the best European university of that time, the University of Gottingen, in the last third of the $18^{\text {th }}$ century (for more details on Schlözer in Russia see Andreev 2000).

\section{REFLECTIONS OF ROMANTICISM}

Thus new tendencies in the intellectual life of Central European states were reflected distinctly in the development of ethnographic ideas. The basis of these ideas was an interest in original old times and "narodnost" (i.e. nationality) expressed in customs, legends, songs and fairy tales. "The Romantic Era" most obviously revealed itself in the period of German Romanticism (Johann G. Fichte, Friedrich L. Jahn) in the 1930s. The appearance of a collection of old German folk songs Des Knaben Wunderhorn (The Youth's Magic Horn) in three parts from 1806 to 1808 was met with a generous response on the part of the German intelligentsia. In 1812 and 1814 respectively, two volumes of Children's and Household Tales, collected by brothers Jacob and Wilhelm Grimm, were published and soon became famous.

Thus Russian folklore studies as a special field of knowledge became prominent at the turn of $18^{\text {th }}$ and $19^{\text {th }}$ century due to a great interest in ancient myths. One of 
the first folkloristics' schools was the mythological one, which declared folklore to be a result of unconscious collective creativity of a "people's soul" (brothers Jacob and Wilhelm Grimm, Alexander N. Afanasyev, Fedor I. Buslaev in Russia). ${ }^{2}$ The following fact played a big role in the development of Russian folklore studies: during the reign of Catherine II, the peasantry suffering under the oppression of serfdom drew the attention of the ruling class with their riots (Pugachev's Rebellion). This attention also extended to the problems of the peasantry and developed also into an interest in the study of creativity, beliefs and customs of the Russian people.

The first collections and publications of works on Russian folk art include the works of Mikhail D. Chulkov (1743-1793). From 1770 to 1774, his Collection of Different Songs and Russian Fairy Tales Containing the Most Ancient Stories about Famous Bogatyrs, Folktales and etc. ${ }^{3}$ (Moscow, 1820) was published in four parts. In addition, one can trace the publication of Russian proverbs to this same period, the earliest of them being a hand list of proverbs in the book Russian Universal Grammar or vseobemlyuschee pismoslovie ${ }^{4}$ written by Nikolai G. Kurganov (Saint Petersburg, 1769). In 1770, the Collection of 4291 Ancient Russian Proverbs in alphabetical order was prepared by A. A. Barsov (II and III edition in 1778 and 1787) and published in Moscow at the university printing house. The first works on Russian and Old Slavic folk beliefs also began to appear during this period. In 1768, Mikhail I. Popov published the collection The Description of Ancient Slavic Fable-Writing, with the second, enlarged edition to follow in 1772. In 1767, Chulkov published The Brief Mythological Lexicon, in which he listed in alphabetical order the names of antique gods, heroes as well as other mythological characters and ideas together with a number of Slavic mythological names. In 1780, Chulkov published The Dictionary of Russian Superstitions working extensively from the collection of Popov and adding significant other material. The second edition was published in 1786 under the title Abevega russkikh sueverii (ABC of Russian Superstitions). In 1804, university professor Dorpat G. Glinka published the little book The Ancient Religion of the Slavs. In the same year, the original edition of the book Slavic and Russian Mythology written by Andrei S. Kaisarov was published (republished in 1810).

The first quarter of the $19^{\text {th }}$ century was marked by an even greater surge of interest in the patriarchal old times among the advanced classes of Russian society. The reaction that increased after the expulsion of Napoleon from Russia was escalating dramatically thereafter, especially due to the development of the liberation movement in Russian society. The organization of secret societies (1816-1825) and the revolt on 14 December 1825 were the objective expression of Russia entering on the new path of capitalist development.

2 For more details about the formation of Russian folklore studies refer to Azadovsky (1958), Putilov (1994) and Anikin (1996).

3 Bogatyrs $=$ folk or epic heroes.

4 Vseobemlyuschee pismoslovie $=$ comprehensive writing. 
Worth noting among the works of that time are The Experience of Narration about Russian Antiquities by G. Uspensky (Part 1, Kharkov, 1811; Part 1, 2, Kharkov, 1818) and The Brief Review of Mythology of Russian Slavs by Pavel M. Stroyev (Moscow, 1815). These works marked the improvement of the scientific method and a critical point of view on the subject of research, and they became a new milestone in the development of Russian folkloristics.

The reactionary forces broke the progressive movement, and, following the defeat of the Dekabrists' revolt, the reactionary regime of Nicholas I was established in the country. By the early 1830s, conservative and reactionary opinions obviously dominated Russian society. This also had an impact on the change in national self-consciousness. The interest in the study of "narodnost" (i.e. nationality) was not lost, and the former passionate interest in the heroic history of the Russian people had transformed into an interest in its patriarchal old times. But under the conservative and reactionary policy of the government, this interest gained a purely conservative reactionary overtone. Not without reason the idea of "narodnost" turned out to be one of the three principles of Nicholas I serfdom regime along with "samoderzhavie" (i.e. autocracy) and "pravoslavie" (i.e. orthodoxy) (Count Uvarov Formulas, 1834). So it is no surprise that in the 1830s the ideas of scholars pursuing the conservative way of thinking began to prevail in the study of people. These were Ivan M. Snegirev, Ivan P. Sakharov and at a later stage Aleksandr V. Tereshchenko and Vladimir I. Dal (Volodimir I. Dahl).

Ivan M. Snegirev (1797-1868) was the son of a professor at Moscow University; he was also a professor at the Department of Latin and Roman Antiquities. At the same time, he began to study the Russian old times in an amateur capacity. Snegirev was considered to be the best expert on Old Moscow: he was an active member of the Moscow Society of Amateurs of Russian Philology (since 1820) and the Moscow Society of History and Antiquities of Russia (serving as its secretary). But he was mostly known for his works devoted to the Russian "narodnost" (i.e. nationality). His first article, 'Russian National Hallery or lubok Pictures' (i.e. popular prints with a brightly-colored picture in primitivist style), was published in Pavel Svinyin's literary magazine Otechestvennye Zapiski (i.e. Annals of the Fatherland or Patriotic Notes) as early as in 1822. Other articles followed, including: 'On Folksy Pictures' (The Works of the Society of Amateurs of Russian Philology, Book IV, 1824), and 'Lubok Pictures of the Russian People in Moscow World' (Moscow, 1844). These texts contained a great deal of information on engravers' work in Russia and gave a detailed description of the popular "lubok" pictures existing in the middle of the $19^{\text {th }}$ century, which he classified according to their subject matter as "spiritual and religious", "philosophical", "legal", "historical" and "symbolic and poetic".

Snegirev began another great project on Russian proverbs during the same period. In 1822, The Complete Edition of Russian Proverbs and Sayings was published. No one had attempted to study the proverbs before Snegirev. At first he devoted to 
Russian proverbs a short article in The Works of the Society of Amateurs of Russian Philology (1823), followed by several other articles published in journals. From 1831 to 1834, he published his great work in four volumes, The Russians in Their Proverbs. Snegirev approached folk proverbs quite rightly as a mirror of the peoples' way of life and their view of the world. He saw in them a reflection of different epochs and different events in Russian history. In a chapter of the work On Foreign Sources of Russian Proverbs, he collected many proverbs of peoples of the East, the ancient world, the Western and the Southern Slavs. Snegirev classified all proverbs based on their content as either "anthropological", "physical" and "historical". In the first category, named so inappropriately, he accumulated the proverbs relating to the natural and moral differences in people (including those related to paganism, faith and superstitions, morality, politics, legal procedures, etc.). Sayings on the weather, farming as well as "medical" cases were classified as proverbs of the "physical" category. The category of "historical" proverbs included those related to any historical event; he divided them into "chronological", "topographical" and "ethnographic". The last category comprised different sayings concerning particular peoples, inhabitants of particular regions and cities, etc. Such a classification, however chaotic it may have been, nevertheless proved that it was necessary to review folk proverbs by applying scientific research methods in order to systematize the expression of people's view of the world.

Snegirev's third and the most famous work was devoted to common holidays. He collected an enormous amount of material on this topic: his own observations, information collected from existing literature, and information received directly from informants, whom he listed in the preface with an expression of thanks. At first Snegirev provides a general theoretical and historical introduction and only then a description of holidays, placing particular holidays into the full-year cycle. At the same time, he provides comparative information on similar phenomena for other world nations, both ancient and contemporary, evidence of his belief in a purely folk and historical basis for holidays. This work has not yet become outdated; it is widely used by modern ethnologists, historians and folklorists. In 1840, the Academy of Sciences awarded the Demidov prize for an outstanding contribution to science to Snegirev's book about holidays.

Ivan P. Sakharov (1807-1863) was even more famous for his scientific works. The son of a priest from the "guberniya" (i.e. governorate) of Tula and educated as a doctor, Sakharov collected and published about ancient monuments with extraordinary diligence. His great achievement was the publication of a considerable number of manuscripts and books printed in old times. His works on Russian numismatics and icon painting were also well known, but he became most famous as a collector of folk tales, songs, fairy tales, popular beliefs and customs. In 1836, he published The Russian People Legends of Family Life of Their Ancestor (Part 1 - 1836; Part 2, 3 - 1837). He also published The Travels of Russian People to Foreign Lands (1837), The Songs of the Russian People (Part 1, 2, 1838), Notes of Russian People and Russian Folktales (1841). The 
success of these works was due to the abundance of material contained in them, part of which was completely new and unknown. The contents of his works corresponded with the demand for knowledge of its peoples in educated society.

The monumental work created by the anthropologist and archeologist Aleksandr V. Tereshchenko (1806-1865) The way of life of Russian people (Parts 1-4, Saint Petersburg, 1848) follows rather consistently a reactionary and romantic opinion. It is devoted to matters of Russian housing, clothing, food, arts and crafts, family life, common law, rites, folk-medicine, folklore as well as the physical type of Russians. The book consists of seven parts combined into four volumes. The first volume contains information on the material culture of Russians - housing, clothing, handicrafts, etc.; the second volume sets out a considerable amount of material about marriage rites. This material is classified according to centuries, social groups (Grand Ducal weddings, Tsarist weddings, weddings of nobles and commoners) and regions - "guberniyas" (i.e. governorates). The third and the fourth volume contain information on chronology, various family and calendar rites and customs, games and "khorovods" (i.e. round dances). Chronologically speaking, the material presented covers the period until the middle of the $19^{\text {th }}$ century. The author proves the originality of Russian cultural identity and its similarity with the culture of the early Slavic peoples.

Russian ethnography is deeply indebted to Vladimir I. Dal (1801-1872). The son of a foreigner (Dane) "raznochinets" (i.e. person of miscellaneous rank) and Protestant by confession, he first received a naval education and then a medical one, working many years in state institutions. V. I. Dal nevertheless is a very important figure in the history of Russian ethnography and folkloristics. From his childhood onward, he was brought up to love everything Russian and took every opportunity over the long years of his professional life to study the language of the people and collected proverbs, fairy tales, popular beliefs, local idioms and dialects. The main purpose of his tireless work, which lasted fifty years, was purely a Slavophile one: the true original spirit of the people was manifested in their language and verbal creativity. Dal regarded the Russian vernacular language with profound respect. The Russian literary language seemed to him damaged by all sorts of foreign influences, and he tried to purify it by means of taking folk speech to extremes in this process. Aged nineteen he already began to notice provincial folk words and phrases (i.e. dialectal words and phrases).

In 1832, he published The Russian Fairy Tales Transcribed in Civilian Letter from Folk Oral Legends, Fitted to Worldly Way of Life and Decorated with Current Sayings by Cossack Vladimir Lugansky, Pyatok pervy ${ }^{5}$ (Saint Petersburg). From 1845 to 1846, he wrote articles about folk beliefs for the magazine Illustration, which were later republished under the title On the Popular Beliefs, Superstitions and Prejudices of the Russian People (Saint Petersburg, Moscow, 1880). In this book, he tries to interpret popular be-

5 Pyatok pervy $=$ the first collection of fairy tales. 
liefs. However, Dal came into real prominence with the publication of two important works: the collection of Russian proverbs and The Explanatory Dictionary (4 volumes, 1863-1866). He published his article about Russian proverbs in the well-known magazine Sovremennik (1847, book 6, section 4). From 1861 to 1862, the periodical Reading of Moscow Society of History and Antiquities of Russia published The Proverbs of the Russian People, in which the author collected thirty thousand proverbs, sayings, riddles, tongue twisters, etc. - the largest collection among the currently existing ones. This collection was prepared by Dal much earlier, as far back as 1853, but pre-reform censorship did not allow it to be printed because of the allegedly seditious content of many proverbs.

The names of Dal as well as Karl M. Baer, Peter I. Keppen, Fyodor P. Litke, Adam Johann von Krusenstern, Mikhail N. Muravyov, Fedor F. Berg, Konstantin I. Arsenyev, Vladimir F. Odoevsky and others were associated with the foundation of the Imperial Russian Geographical Society in 1845. Its inaugural meeting was held in Dal's apartment in Saint Petersburg. The Society had following departments: the common geography of Russia, statistics and ethnography (the first two departments were soon merged). With the foundation of the Imperial Russian Geographical Society, Russian ethnography entered a new stage of its development, which should be described in full in a separate chapter.

\section{FORMATION OF UNIVERSITY DEPARTMENTS}

As was already mentioned, the foundation of the Russian Academy of Sciences in 1725 played an important role in the formation of Russian ethnography. The driving scientific forces of the Academy understood the need for the development of scientific programs. Description of Kamchatka Land written by Stepan Krasheninnikov was one of the results of his expedition. An instruction was drawn up for this expedition, with a great deal of its questions focusing on the boundaries of different peoples' settlements, customs, rites and language. In addition to this brief instruction, Müller and his colleagues used the survey drawn up in 1734 by Vasily Tatishchev in order to study the history and geography of Siberia. Most of the questions were of a purely ethnographic nature. With all additions made in 1737, this questionnaire consisted of 198 questions and was sent to the administrations of Siberian and Volga provinces and cities. These materials were then sent from the local areas back to the Saint Petersburg Academy of Sciences.

The organization of the planned and systematic collection of ethnographic material as well as the origin of ethnographic programming in Russia were associated with the foundation of the Imperial Academy of Sciences, and later in 1765 with the Imperial Free Economic Society. The first survey sent out throughout Russia in 1765 by the Free Economic Society addressed the economic problems associated with agriculture 
in different "guberniyas" (i.e. administrative regions); in addition, it included a range of questions relating to ethnography (concerning crafts, folk fairs, handicrafts, agriculture, fishery, cattle breeding).

The need to study the Slavic peoples from abroad arose in 1835 , due also in large part to the formation of departments of history and literature of Slavic dialects and the cadre of Slavic scholars in central Russian universities - Moscow, Saint Petersburg, Kazan and Kharkov. In the late 1830s, the future professors of Russian universities were sent to Slavic lands: Moscow university - Osip M. Bodyansky (1808-1877), Saint Petersburg university - Pyotr I. Preis (1810-1846), Kharkov university - Ismail I. Sreznevsky (1812-1880) and Kazan - Viktor I. Grigorovich (1815-1876). Enthusiastic and intelligent, they became the first university Slavic scholars of Russia, who greatly contributed to the formation of the ethnographic Slavic studies. The main subject of their studies was Slavic philology; however, they all clearly understood the necessity for the development of ethnography as an independent field of knowledge. They wrote and talked about its content, placing special emphasis on the ethnography of one or another people in their lectures. From 1839 to 1842, the professor of the Slavic department of Saint Petersburg University Pyotr I. Preis travelled to foreign Slavic lands. Making preparations for the journey, he drew up what was for that time a unique survey that consisted of eight sections and included 167 questions, 108 of which covered ethnic history, economy, handicrafts, commerce, governance, family and social way of life, folk beliefs and mythology of the Serbs, the Montenegrins, the Croats and the Slovenes. Pyotr Preis died at age of 36 and therefore did not have time to publish his program. The full text of the program manuscript is still kept in the archives of the Russian Academy of Sciences in Saint Petersburg. ${ }^{6}$

Thus we have presented a brief review of the conditions in Russian ethnography over the course of a century (1750-1850), having highlighted only the key milestones in its formation and development.

\section{REFERENCES}

Andreev, Aleksandr I. (ed.)

1948 Polnoe sobranie Russkie otkrytiya v Tikhom okeane i Severnoy Amerike v XVIII v. (Russian Discoveries in the Pacific Ocean and North America in the Eighteenth Century) Moskva: Geografgiz.

Andreev, Andrei Yu.

2000 "Gettingenskaya dusha" Moskovskogo universiteta Iz istorii nauchnykh vzaimosvyazey Moskvy i Gettingena $v$ nachale stoletiya Voprosy istorii yestestvoznaniya i tekhniki. N 2. ("Gottingen Soul" of

6 For the full text of the ethnographic program by Pyotr I. Preis refer to Saint Petersburg branch of the archives of the Russian Academy of Sciences. Fund 106. List 1. File 5. Sheets 1-5. (Polnyy tekst etnograficheskoy programmy P. I. Preysa sm Peterburgskiy filial arkhiva Rossiyskoy Akademii nauk. PF ARAN. Fond 106. Op 1. D. 5. L.1- 5.) 
Moscow University. From the History of Scientific Relations between Moscow and Gottingen at the Beginning of the Nineteenth Century. Questions Concerning the History of Natural Sciences and Engineering. N 2.) Moskva: Nauka.

Anikin, Vladimir P.

1996 Teoriya fol'klora. Kurs lektsiy. (Theory of Folklore: A Series of Lectures.) Moskva: KDU.

Azadovsky, Mark K.

1958-1963 Istoriya russkoy fol'kloristiki: V2-ht. (The History of Russian Folklore Studies: In Two Volumes.) Moskva: Nauka.

Gaim, R. (Heym, Rudolf)

1888 Gerder yego zhizn' i sochineniya. I-II. (Herder, His Life and Works. Vol. I, II.) Izdanie K. T. Soldatenkova Tip-ya V. F. Rikhter. Moskva.

Georgi, Johann G.

1776-1777 Opisanie vsekh v Rossiyskom gosudarstve obitayushchikh narodov Takzhe ikh zhiteyskikh obryadov ver obyknoveniy zhilishch odezhd i prochikh dostopamyatnostey. Ch. 1-4. (A Description of All the Peoples Living in the Russian State, also Their Worldly Rites, Religions, Habits, Houses, Clothes and Other Memorablenesses. Part 1-4.) Sankt Peterburg.

Herder, Johann G.

1803 Outlines of a philosophy of the history of man. Tr. from the German of John Godfrey Herder by T. Churchill. Printed by Luke Hansard for J. Johnson.

1829 Mysli otnosyashchiesya k filosofskoy istorii chelovechestva po razumeniyu i nachertaniyu Gerdera. Russkiy perevod. (Thoughts Relating to the Philosophical History of Humanity in Herder's Opinion and Writing: Russian Translation.) Sankt Peterburg.

1959 Izbrannye sochineniya. (Selected Works.) Moscow, Leningrad: Gosudarstvennoe izdateljstvo hudozhestvennoi literaturi.

Lomonosov, Mikhail V.

1950-1983 Polnoe sobranie sochinenii. (Complete Edition). Moscow, Leningrad: Akademiia nauk SSSR.

Putilov, Boris N.

1994 Fol'klor i narodnaya kul'tura. (Folklore and Folk Culture.) Sankt Peterburg: Knizhni dom »Universitet«.

Snegirev, Ivan

1837-1839 Russkie prostonarodnye prazdniki i sueveriya. Vyp. 1-4. (The Common Holidays of Russians and Superstitions. Ed. 1-4.) Moskva: Universitetskaja tipografija.

Tokarev, Sergei A.

1966 Istoriya russkoy etnografii. (A History of Russian Ethnography.) Moskva: Nauka.

1978 Istoki etnograficheskoy nauki. (Origins of Ethnographic Science.) Moskva: Nauka.

\section{OBLIKOVANJE RUSKE ETNOGRAFIJE (1750-1850)}

Avtorica v prispevku pojasni, kako se je ruska etnografija oblikovala v drugi polovici 18. stoletja in prvi polovici 19. stoletja, pri čemer ta časovni razpon razdeli na več krajših obdobij. Sprva so na nastajajočo vedo pomembno vplivale raziskovalne odprave $v$ neznane predele Rusije, ki so jih spodbujali in izvajali v novonastali Ruski akademiji znanosti. Na podlagi izsledkov teh odprav je nastalo tudi prvo pomembnejse etnografsko delo z naslovom Opis 
vseh ljudstev, živečih v državi Rusiji (Georgi 1776-1777). V tem delu je bil predstavljen pregled ljudstev $v$ Ruskem cesarstvu in podan opis njihovih ekonomij ter načinov življenja. Posebej so poudarjena še ruska popotovanja po svetu, ki so v prvi polovici 19. stoletja potekala predvsem zaradi tedanjih ekonomskih in političnih razmer. Rusija je namreč skušala povezati z območji v Severni Ameriki (npr. Aljaska in Aleuti), ki so jih pridobili, ter organizirati preskrbo tamkajšnjih kolonij. Med temi potovanji so raziskovalci odkrili tudi nova območja in otoke ter opisali prebivalce v oddaljenih deželah.

Zelo pomemben posameznik, ki je omogočil utrditev etnografije kot znanosti, je bil $V . M$. Lomonosov (1711-1765). S svojo Rusko slovnico (1757) je postavil temelje znanstvenega preučevanja ruskega jezika in slovničnih struktur ter ruske dialektologije. Lomonosov je tudi pisec del o načinu življenja ruskega naroda, pri čemer je poudaril številne slabe navade, ki so ustavljale rast prebivalstva in vplivale na visoko smrtnost ljudi.

Pomembno vlogo pri oblikovanju ruske etnografije so imela tudi dela nekaterih zahodnih znanstvenikov. Posebej vpliven je bil nemški filozof J. G. Herder (1744-1803) s širokim razponom interesov: od literature, umetnosti, teorije estetike in lingvistike do zgodovine. Morda najpomembnejša zamisel, ki Herderja loči od francoskih razsvetljencev, je koncept "nacionalnega duha", ki je postal pomemben tudi v ruski etnografiji.

$V$ prispevku je poudarjen tudi pomen A. L. Schlözerja (1735-1809), ki je prvi razumel zgodovino kot vedo, ki preučuje državo, kulturo in versko življenje, poleg tega pa je v zgodovinopisje vključil še statistiko, politiko, geografijo in etnografijo. Schlözerjeva dela so vila pomemben vmesnik v procesih kulturnih izmenjav med Evropo in Rusijo v drugi polovici 18. in prvi polovici 19. stoletja.

I. M. Snegirev (1797-1868) je zaslovel s prispevki o ruski narodnosti. Med letoma 1831 in 1834 je izdal osrednje delo v štirih zvezkih z naslovom Rusi v svojih pregovorih. Vtem delu je predstavil ljudske pregovore kot odsev načina življenja ljudi in njihovega pogleda na svet, $v$ pregovorih pa je videl odslikavo razlicnih obdobij in dogodkov iz ruske zgodovine. Tretje in najpomembnejše delo Snegireva pa je o praznikih; tudi o tej temi je zbral ogromno relevantnih gradiv.

Predstavljeni so še nekateri drugi posamezniki, ki so pomembno prispevali k razvoju etnografije v Rusiji, npr. zbiralec ljudskih pesmi, povedk, verovanj in običajev I. P. Saharov (1807-1863), antropolog in arheolog A. V. Tereščenko (1806-1865) in folklorist V. I. Dal (1801-1872). V njegovem stanovanju v Sankt Peterburgu so leta 1845 ustanovili Rusko imperialno geografsko društvo.

Dr. Mariam M. Kerimova, senior researcher, N. Mikluho-Maklay Institute of Ethnology and Anthropology, Russian Academy of Sciences, Leninsky Prospekt 32A, 117334 Moscow, Russian Federation 